\begin{tabular}{|l|l|l||}
\hline \multicolumn{2}{|c|}{ PublisherInfo } \\
\hline \hline PublisherName & $:$ & BioMed Central \\
\hline \hline PublisherLocation & $:$ & London \\
\hline \hline PublisherImprintName & $:$ & BioMed Central \\
\hline \hline
\end{tabular}

\title{
Healing with stem cells
}

\begin{tabular}{|l|l|l||}
\hline \multicolumn{2}{|c|}{ ArticleInfo } \\
\hline \hline ArticleID & $:$ & 4036 \\
\hline \hline ArticleDOI & $:$ & $10.1186 /$ gb-spotlight-20010403-01 \\
\hline \hline ArticleCitationID & $:$ & spotlight-20010403-01 \\
\hline \hline ArticleSequenceNumber & $:$ & 107 \\
\hline \hline ArticleCategory & $:$ & Research news \\
\hline ArticleFirstPage & $:$ & 1 \\
\hline \hline ArticleLastPage & $:$ & 2 \\
\hline \hline & & RegistrationDate : 2001-04-03 \\
ArticleHistory & $:$ & OnlineDate \\
\hline \hline ArticleCopyright & $:$ & BioMed Central Ltd2001 \\
\hline \hline ArticleGrants & $:$ & \\
\hline \hline ArticleContext & $:$ & 130592211 \\
\hline \hline
\end{tabular}




\section{Tudor Toma}

Email: ttoma@mail.dntis.ro

Progressive heart failure and death can occur following myocardial infarction due to ventricular remodelling and fibrosis. Neoangiogenesis occurs normally within the infarcted tissue, but the new capillary network is unable to support the greater demands of the hypertrophied myocardium and remaining myocytes are unable to reconstitute the necrotic tissue.

In the April Nature Medicine, Kocher and colleagues Columbia University, New York show that bone marrow from adult humans can be used to help neoangiogenesis and directly induce new blood vessel formation in the infarct area.

They used selected bone marrow cells from human donors and athymic rat recipients with ligationinduced coronary thrombosis as an experimental model of infarction. Kocher et al showed a significant increase in revascularization of post-infarction myocardial tissue after the intravenous administration of CD34+ human stem cells. The neoangiogenesis resulted in decreased apoptosis of hypertrophied myocytes in the peri-infarct region, long-term salvage and survival of viable myocardium, reduction in collagen deposition and sustained improvement in cardiac function (Nat Medicine 2001, 7:430-437).

A separate study published in 5 April Nature demonstrates that myocardium itself can be restored by stem cells. Piero Anversa and colleagues at New York Medical College showed that dead myocardium could be restored in $68 \%$ of the infarcted portion by transplanting lineage-negative (Lin- ) bone marrow cells in infarcted mice. They sorted Lin- cells from transgenic mice expressing enhanced green fluorescent protein by fluorescent-activated cell sorting (Nature 2001, 410:701-705).

Improving the reperfusion and myocyte numbers of ischaemic human myocardium with stem cells is now becoming a viable option, but many issues remain to be clarified. Obtaining adequate numbers of autologous cells from a heart attack patient, in sufficient time to prevent remodelling may still prove difficult.

\section{References}

1. Kocher AA, Schuster MD, Szabolcs MJ, Takuma S, Burkhoff D, Wang J, Homma S, Edwards NM, Itescu S: Neovascularization of ischemic myocardium by human bone-marrow-derived angioblasts prevents cardiomyocyte apoptosis, reduces remodeling and improves cardiac function. Nat Medicine 2001, 7:430-437., [http://www.nature.com/nm/] 
2. Columbia University, New York, [http://www.columbia.edu/]

3. Orlic D, Kajstura J, Chimenti S, et al: Bone marrow cells regenerate infarcted myocardium. Nature 2001, 410:701-705., [http://www.nature.com]

4. New York Medical College, [http://www.nymc.edu]

5. Rosenthal N, Tsao L: Helping the heart to heal with stem cells. Nat Medicine 2001, 7:412-413., [http://www.nature.com/nm/]

This PDF file was created after publication. 